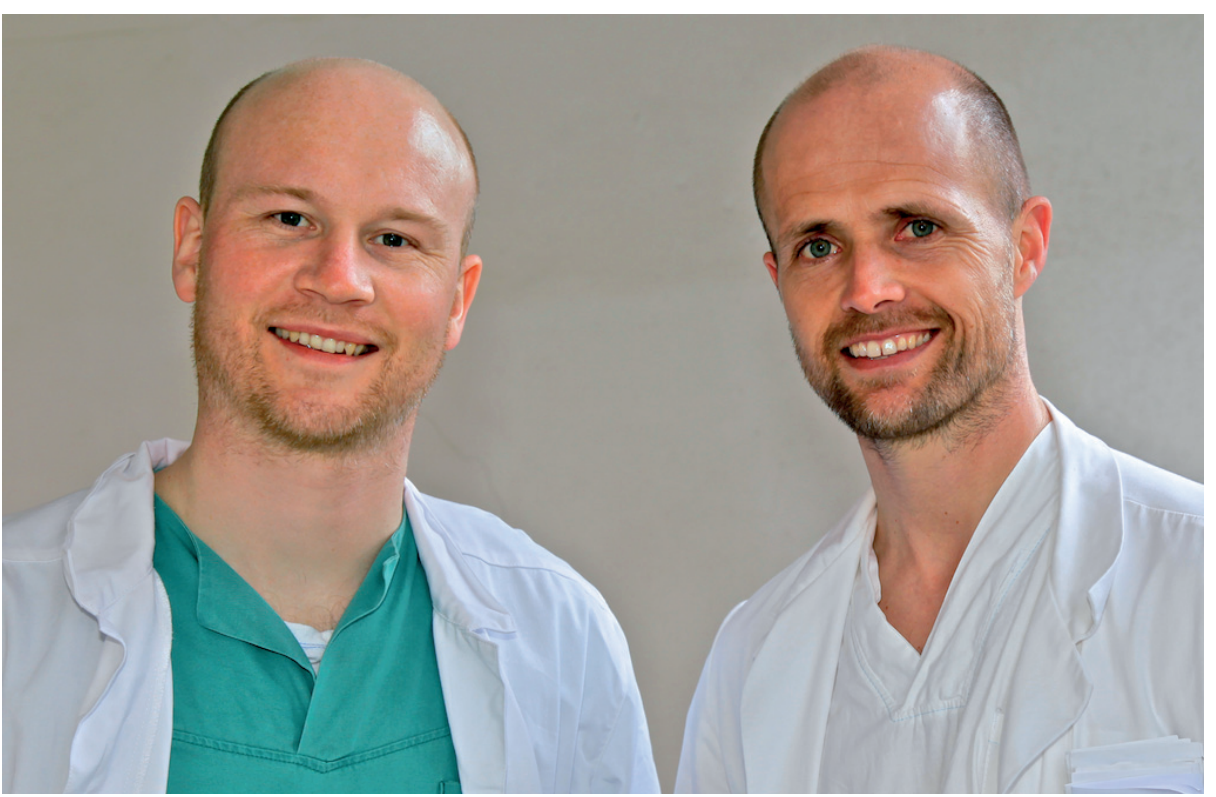

Kjetil Søreide og Terje Meling. Foto privat

\section{Klassifikasjonssystem for beinbrudd fungerer bra}

Det er godt samsvar i klassifiseringen av beinbrudd mellom ulike kirurger og av samme kirurg på ulikt tidspunkt. Dette viser en ny studie fra Stavanger.

Klassifikasjonssystemer for beinbrudd gjør det mulig å sammenlikne behandling og behandlingsresultater, men studier har vist at det er vanskelig å klassifisere beinbrudd på en god og ensartet måte. Det mest brukte klassifikasjonssystemet for beinbrudd er AO/OTA-klassifikasjonen, som er basert på klassifikasjon av bruddets anatomiske plassering og deretter bruddets morfologi.

Alle brudd i de lange rørknoklene hos voksne pasienter som ble behandlet ved Stavanger universitetssjukehus i 2008 ble klassifisert til én av 13 anatomiske segmenter, og deretter i én av ni morfologisk forskjellige bruddgrupper (1). Bruddene ble klassifisert på nytt av samme kirurg for måling av intraobservatørreliabilitet. Halvparten av bruddene ble også klassifisert av en annen kirurg for vurdering av interobservatørreliabilitet. En referanse for måling av hvor korrekt klassifikasjonen var, ble utarbeidet.

- Rundt $70 \%$ av bruddene var klassifisert likt ved de tre vurderingene. Dette tilsvarer en kappa-verdi på 0,70 , som må anses som tilfredsstillende, sier studiens førsteforfatter Terje Meling. Regresjonsanalyse viste at økende erfaring ikke ga bedre klassifisering, men at sjeldne bruddtyper og utvalgte anatomiske segmenter var vanskeligere å klassifisere.

- AO/OTA-klassifikasjonen av brudd i lange rørknokler ser ut til å gi akseptabel reliabilitet i daglig bruk i en ortopedisk avdeling til tross for mange involverte kirurger med variabel klassifikasjonserfaring, sier Meling.

\section{Kirurgisk forskning i Stavanger}

Artikkelen er skrevet av Terje Meling, Knut Harboe, Cathrine Enochsen, Morten Aarflot, Astvaldur Arthursson og Kjetil Søreide. Terje Meling er overlege og ph.d.kandidat ved Ortopedisk avdeling, Stavanger universitetssjukehus, hvor også Harboe, Enochsen og Arthursson er ansatt. Aarflot er statistiker ved Universitetet i Stavanger. Kjetil Søreide er veileder for Meling og arbeider som kirurg ved Stavanger universitetssjukehus og professor ved Universitetet i Bergen. Prosjektet utgår fra kirurgisk forskningsgruppe ved Stavanger universitetssjukehus, som fikk vurderingen «excellent» ved Norges forskningsråds fagevaluering i 2011.

\section{Erlend Hem}

erlend.hem@medisin.uio.no

Tidsskriftet

\section{Litteratur}

1. Meling T, Harboe $\mathrm{K}$, Enoksen $\mathrm{CH}$ et al. How reliable and accurate is the AO/OTA comprehensive classification for adult long-bone fractures? J Trauma Acute Surg 2012; e-publisert 2.5.2012. doi: 10.1097/TA.0b013e31824cf0ab.
Ordforklaringer

AO/OTA-klassifikasjon: Klassifikasjonssystem introdusert av Maurice E. Müller i 1979, som det første som omfattet alle de lange rørknokler. Først klassifiseres bruddets anatomiske plassering (f.eks. i lårbeinsskaftet) og deretter bruddets morfologi (f.eks. enkelt skråbrudd). Klassifikasjonssystemet har fått stor anvendelse innen bruddforskning. Systemet har fått navn etter de to ledende traume-ortopediske foreningene Arbeitsgemeinschaft für Osteosynthesefragen (AO) og Orthopedic Trauma Association (OTA).

Intraobservatørreliabilitet: Samsvar over tid for samme observatør.

Interobservatørreliabilitet: Samsvar mellom ulike observatører.

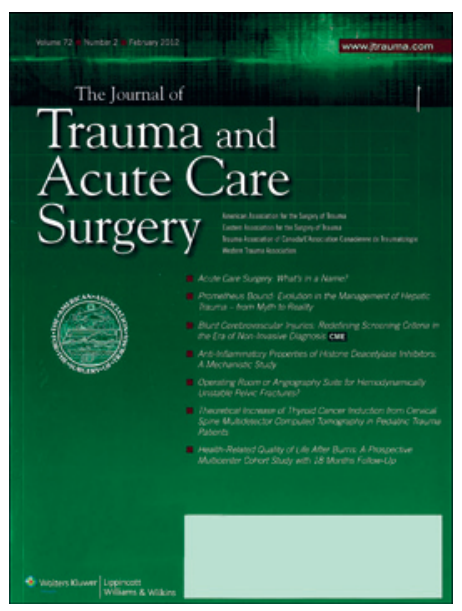

Artikkelen ble e-publisert 2.5. 2012 i Journal of Trauma and Acute Care Surgery (http:// journals.(ww.com/jtrauma), som er det høyest rangerte traumetidsskriftet. 